\title{
ABSTINENSI SEKSUAL REMAJA SMP DI KOTA TANGERANG SELATAN
}

\author{
Sexual Abstinence among Adolescents at Junior High School in South Tangerang City \\ Mizna Sabilla ${ }^{1, *}$, Nurfadhilah $^{2}$ \\ ${ }^{1,2}$ Fakultas Kesehatan Masyarakat Universitas Muhammadiyah Jakarta \\ Jl. K.H. Ahmad Dahlan, Cireundeu, Ciputat, Kota Tangerang Selatan, Banten, Indonesia \\ "E-mail: mizna.sabilla@umj.ac.id
}

Naskah masuk 11 September 2020; review 28 September 2020; disetujui terbit 18 November 2020

\begin{abstract}
Background: Indonesia is projected to experience the peak of the demographic bonus in 2030. The demographic bonus can turn into a burden if adolescents who are successors are not qualified. Adolescent who are supposed to be $100 \%$ absent from sex actually showed an unsatisfactory proportion in several areas.

Objective: This study aimed to describe abstinence behavior among adolescents at junior high school in South Tangerang City.

Method: This study used a cross sectional design. The study population was junior high school students by selecting 25 junior high schools as the sample. The number of samples were 165 students who were taken incidentally. Data was collected from December 2019 to January 2020 by filling out a questionnaire through interviews.

Result: The proportion of abstinence among junior high school students was $80 \%$. The highest abstinence was occurred among adolescent boys and aged 12 years. Most of them carried out positive activities such as art, organization, regular worship, regular exercise, and courses. Most of them admitted that they did not feel seduced, coerced and threatened to have sexual activity. When a sensitive part of the body was touched, respondents acted assertively by refusing, shouting, and hitting.

Conclusion: Sexual abstinence among adolescents at junior high school in South Tangerang needs to be increased. Understanding the importance of abstinence needs to be given to adolescents from the onset of puberty by parents, school environment (school organizations and PIKR) and community (religious organizations).
\end{abstract}

Keywords: Sexual abstinence, Adolescent at Junior High School, South Tangerang

\begin{abstract}
Abstrak
Latar belakang: Indonesia akan mengalami puncak bonus demografi pada tahun 2030. Bonus demografi dapat berbalik menjadi beban apabila remaja yang menjadi penerus tidak berkualitas. Remaja yang seharusnya 100 persen absen seks justru menunjukkan proporsi yang tidak menggembirakan di beberapa wilayah.

Tujuan: Penelitian ini bertujuan untuk mengetahui gambaran perilaku abstinensi pada remaja usia SMP di Kota Tangerang Selatan.

Metode: Penelitian menggunakan desain cross-sectional. Populasi penelitian adalah remaja usia SMP dengan memilih 25 SMP sebagai sampel. Jumlah sampel sebanyak 165 siswa/siswi yang diambil secara insidentil. Pengumpulan data dilakukan pada Desember 2019 sampai Januari 2020 dengan pengisian kuesioner melalui wawancara.

Hasil: Proporsi abstinensi seksual remaja SMP sebesar 80 persen. Abstinensi tertinggi dialami oleh remaja lakilaki dan usia 12 tahun. Sebagian besar melakukan kegiatan positif seperti seni, berorganisasi, rutin beribadah, rutin berolahraga, dan mengikuti seminar/kursus. Sebagian besar responden mengaku tidak pernah merasa dirayu, dipaksa dan diancam untuk melakukan aktivitas seksual. Apabila bagian tubuh sensitifnya disentuh responden melakukan tindakan asertif dengan menolak, berteriak, dan memukul.

Kesimpulan: Abstinensi seksual remaja SMP di Tangerang Selatan harus ditingkatkan. Orang tua perlu menjaga dan mengawasi pergaulan anaknya. Pemahaman agama dan pentingnya abstinensi perlu diberikan kepada remaja semenjak awal pubertas dari orang tua, lingkungan sekolah dan masyarakat melalui organisasi keagamaan dan PIKR
\end{abstract}

Kata kunci: Abstinensi seksual, Remaja SMP, Tangerang Selatan 


\section{PENDAHULUAN}

Indonesia saat ini mengalami bonus demografi yang puncaknya diperkirakan pada tahun 2030. Proporsi penduduk Indonesia lebih banyak pada kelompok usia produktif dibandingkan usia non-produktif (kurang dari 15 tahun dan 65 tahun ke atas). Bonus demografi ini dapat terbalik menjadi beban demografi apabila generasi penerus tidak dipersiapkan dengan baik. Generasi penerus yang akan menjadi usia produktif di masa tersebut adalah kelompok remaja saat ini. Sebagaimana hasil Survei Penduduk Antar Sensus (SUPAS) 2015 melaporkan bahwa penduduk Indonesia sebagian besarnya adalah kelompok usia muda yang diantaranya adalah remaja usia 10-18 tahun ${ }^{1}$. Remaja inilah yang harus dipersiapkan untuk menghadapi puncak bonus demografi dalam satu dekade mendatang.

Bonus demografi semakin di depan mata, akan tetapi fakta dan angka terkait permasalahan remaja masih tidak menggembirakan. Survei Demografi dan Kesehatan (SDKI) 2017 tentang kesehatan reproduksi remaja melaporkan presentase seks pranikah pada remaja usia 1519 tahun pada laki-laki sebanyak 3,6 persen dan usia 20-24 tahun 14,0 persen, sedangkan pada wanita usia 15-19 tahun sebesar 0,9 persen dan usia 20-24 tahun 2,6 persen ${ }^{2}$. Angka tersebut tidak menunjukkan penurunan daripada laporan SDKI 2012. Hubungan seksual pranikah pada remaja dapat mengancam remaja putri mengalami kehamilan yang tidak diinginkan (KTD), aborsi, penularan Infeksi Menular Seksual (IMS) dan HIV-AIDS, trauma kejiwaan, serta kemungkinan tidak melanjutkan pendidikan ${ }^{3}$. Beberapa peneliti beranggapan bahwa rendahnya abstinensi seks yang berkelanjutkan akan berdampak pada kerusakan moral remaja ${ }^{4}$.

Abstinensi seks berarti tidak melakukan hubungan seksual secara oral, anal maupun vaginal $^{5}$. Terdapat beberapa frase dalam mendefinisikan abstinen, yaitu 'abstain dari

\footnotetext{
* Korespondensi penulis

(mizna.sabilla@umj.ac.id)
}

(C) Badan Penelitian dan Pengembangan Kesehatan ISSN: 2354-8762 (elektronik); ISSN: 2087-703X (cetak) seks', 'berhenti seks' dan 'tidak ingin berhubungan seks', yang intinya adalah 'tidak melakukan hubungan seksual ${ }^{6}$. Ahli kesehatan umumnya memandang abstinensi sebagai masalah perilaku atau kesehatan, menggunakan istilah seperti "menunda hubungan seks", "tidak pernah melakukan hubungan seks vaginal", atau menahan diri untuk tidak melakukan hubungan seksual (intercourse) lebih lanjut ${ }^{7}$. Abstain dari semua bentuk aktivitas seksual 100 persen aman dan menjadi cara efektif untuk menghindari KTD pada remaja dan IMS ${ }^{8}$.

Persentase abstinensi beragam di berbagai negara. Di Nigeria, 68 persen remaja perempuan belum pernah melakukan hubungan seksual (abstinensi) ${ }^{9}$. Di Amerika, Youth Risk Behavior Surveillance melaporkan terdapat 39,5 persen pelajar tingkat menengah yang sudah melakukan hubungan seksual (intercourse), artinya terdapat 61,5 persen pelajar yang abstinensi ${ }^{10}$. Hasil systematic review artikel di Asia, Afrika, Australia, Eropa dan Amerika Utara, proporsi abstinensi pada remaja pria (10-24 tahun) berkisar antara 3,483,3 persen dengan proporsi terbesar pada remaja awal usia $10-14$ tahun $(27,7 \%-83,3 \%)^{11}$.

Faktor-faktor yang berhubungan dengan abstinensi antara lain faktor demografi (usia, status berpacaran, status pekerjaan, pendapatan, dan status tempat tinggal); faktor lain seperti kesehatan dan penyakit, self-esteem, keyakinan (belief), dan persepsi tentang abstinensi, aspek sosial dan keluarga, religiusitas, merokok dan penyalahgunaan obat, serta pendidikan seks ${ }^{11}$. Penelitian di Ghana menemukan bahwa komunikasi seksual dengan kedua orang tua adalah satu-satunya faktor yang memprediksi kemungkinan abstinensi seks yang lebih tinggi ${ }^{12}$. Penelitian di Nigeria juga memperoleh hasil bahwa kehadiran orang tua dalam rumah tangga berhubungan dengan abstinensi remaja. Faktor religiusitas juga menjadi faktor protektif dari perilaku seksual. Remaja dengan tingkat religiusitas yang tinggi berpeluang 2 kali lebih besar untuk berperilaku abstinensi ${ }^{9}$. 
Di Indonesia penelitian yang mengkaji perilaku abstinensi seksual masih terbatas. Penelitianpenelitian terdahulu lebih memusatkan perhatian pada perilaku seksual remaja. Sebuah penelitian di DKI Jakarta menyebutkan bahwa proporsi remaja SMP yang berperilaku abstinensi sebanyak 65 persen ${ }^{13}$. Angka yang cukup tidak menggembirakan karena hampir separuh remaja yang menjadi sampel sudah pernah melakukan hubungan seksual. Di sebuah SMPN di Tangerang, proporsi abstinensi jauh menyedihkan, yaitu 38,4 persen. Artinya sebagian besar siswa/siswi SMP tersebut pernah melakukan seks pranikah ${ }^{14}$. Proporsi tersebut menunjukkan angka yang jauh lebih rendah daripada proporsi abstinensi pada Survei Nasional Berbasis Sekolah $(94,7 \%)^{15}$.

Kota Tangerang Selatan merupakan salah satu kota penyangga ibu kota Jakarta yang memiliki karakteristik yang hampir sama. Berdasarkan penelitian pada siswa-siswi SMA di Tangerang Selatan, diketahui bahwa 2,8 persen remaja pernah melakukan hubungan seksual, dengan proporsi abstinensi sebesar 90,8 persen, meliputi 53,2 persen perempuan dan 46,8 persen laki-laki ${ }^{16}$. Penelitian perilaku seks bebas pada mahasiswa di Tangerang Selatan menunjukkan proporsi abstinensi sebesar 90,6 persen pada laki-laki dan 98,1 persen pada perempuan ${ }^{17}$. Sejauh ini belum ada penelitian mengenai abstinensi pada remaja SMP di Tangerang Selatan. Usia SMP (12-15 tahun) merupakan remaja awal di mana remaja mulai merasakan ketertarikan kepada lawan jenis dan memiliki rasa keingintahuan yang tinggi untuk mencoba hal-hal baru. Upaya pemberian pemahaman mengenai pentingnya abstinensi seksual dapat dilakukan sedini mungkin pada tingkatan usia tersebut. Oleh sebab itu peneliti bermaksud mengkaji perilaku abstinensi pada remaja usia SMP di Kota Tangerang Selatan.

\section{METODE}

Penelitian ini menggunakan pendekatan kuantitatif deskriptif dengan rancangan potong lintang (cross sectional). Populasi penelitian adalah remaja SMP di Kota Tangerang Selatan. Pemilihan sekolah dilakukan secara purposif yaitu SMP Negeri, MTS Negeri, SMP Muhammadiyah, SMP Islam berasrama dan SMP Islam Terpadu berjumlah 25 sekolah. Penelitian dilakukan pada bulan Desember
2019 sampai Januari 2020. Pemilihan sampel dengan cara insidentil. Jumlah sampel minimal ditentukan dengan menggunakan rumus estimasi satu proporsi, diperoleh hasil sebanyak 150 responden, ditambah 10 persen untuk mengantisipasi missing data sehingga menjadi 165 responden.

Pengumpulan data dilakukan dengan metode wawancara oleh enumerator yang telah dilatih. Sebelum wawancara dilakukan, responden diminta menandatangani pernyataan kesediaan untuk memberikan informasi untuk kepentingan penelitian. Responden dapat mengundurkan diri jika mendapati pertanyaan yang tidak bersedia dijawab. Data dimusnahkan setelah penelitian selesai. Kuesioner terdiri dari 17 pernyataan terkait perilaku dan karakteristik responden. Gambaran perilaku abstinensi dibagi menjadi empat bagian, yaitu tiga pernyataan aktivitas seksual, enam pernyataan aktivitas menghindari hasrat seksual, empat pernyataan inisiasi aktivitas seksual, dan empat pernyataan tindakan asertif. Kuesioner diuji validitas dan reliabilitas dengan nilai Alpha Cronbach 0,926. Analisis data dilakukan secara univariat dari setiap item pernyataan dengan perangkat lunak SPSS 24.

\section{HASIL}

Berdasarkan karakteristiknya (tabel 1) diketahui bahwa sebagian besar responden berjenis kelamin laki-laki sebanyak 55,2 persen, bersekolah di sekolah swasta sebanyak 54,5 persen, sekolah tidak berasrama sebanyak 73,3 persen dan sekolah berbasis agama Islam sebanyak 63,6 persen.

Berdasarkan aktivitas seksual (tabel 2), diketahui bahwa sebagian besar siswa tidak pernah intercourse sebanyak 83,6 persen, tidak pernah anal seks sebanyak 84,2 persen, serta tidak pernah oral seks sebanyak 84,2 persen. Dari berbagai aspek aktivitas hubungan seksual tersebut, ada dua kategori yang digunakan, yaitu abstinensi dan tidak abstinensi sebagaimana ditunjukkan pada tabel 3. Tabel 3 menunjukkan bahwa terdapat 80 persen remaja yang abstinen, sedangkan sisanya (20\%) tidak abstinen karena pernah melakukan hubungan seksual berupa memasukkan kelamin ke kelamin, mulut atau anus. 
Tabel 1. Distribusi Frekuensi Karakteristik Responden

\begin{tabular}{lcc}
\hline \multicolumn{1}{c}{ Variabel } & n & \% \\
\hline Jenis kelamin & & \\
Laki-laki & 91 & 55,2 \\
Perempuan & 74 & 44,8 \\
Usia (tahun) & & \\
12 & 11 & 6,7 \\
13 & 44 & 26,7 \\
14 & 81 & 49,1 \\
15 & 29 & 17,6 \\
Jenis sekolah & & \\
Negeri & 75 & 45,5 \\
Swasta & 90 & 54,5 \\
Ketersediaan asrama & & \\
Berasrama & 44 & 26,7 \\
Tidak berasrama & 121 & 73,3 \\
Berbasis agama Islam & & \\
Islam & 105 & 63,6 \\
Umum & 60 & 36,4 \\
\hline Total & 165 & 100,0 \\
\hline
\end{tabular}

Tabel 2. Sub-variabel Aktivitas Seksual

\begin{tabular}{lcc}
\hline \multicolumn{1}{c}{ Sub - Variabel } & n & \% \\
\hline Memasukkan/dimasukkan kelamin ke kelamin/intercourse & & \\
Tidak pernah & 138 & 83,6 \\
Pernah & 27 & 16,4 \\
Memasukkan/dimasukkan kelamin ke anus/anal & & \\
$\quad$ Tidak pernah & 139 & 84,2 \\
$\quad$ Pernah & 26 & 15,8 \\
Memasukkan/dimasukkan kelamin ke mulut/oral & & \\
Tidak pernah & 136 & 82,4 \\
$\quad$ Pernah & 29 & 17,6 \\
\hline Total & 165 & 100 \\
\hline
\end{tabular}

Tabel 3. Distribusi Frekuensi Abstinensi

\begin{tabular}{lcc}
\hline \multicolumn{1}{c}{ Abstinensi } & $\mathbf{n}$ & \% \\
\hline Iya & 132 & 80 \\
Tidak & 33 & 20 \\
\hline Total & 165 & 100 \\
\hline
\end{tabular}

Berdasarkan tabel 4 diketahui bahwa responden laki-laki memiliki proporsi yang lebih besar untuk tidak melakukan intercourse $(57,2 \%)$ dan anal seks $(55,4 \%)$. Perempuan lebih banyak yang melakukan aktivitas menghindari hasrat seksual seperti ikut kegiatan seni, organisasi ibadah dan berolahraga. Semua responden perempuan tidak pernah dipaksa secara fisik, diancam dan dipaksa dengan kekerasan untuk melakukan aktivitas seksual. Responden perempuan juga lebih banyak bertindak asertif ketika bagian tubuh sensitif disentuh, seperti menolak $(66,2 \%)$, berteriak $(63,5 \%)$, dan memukul $(75,7 \%)$. 
Tabel 4. Perilaku berkaitan Abstinensi Seksual berdasarkan Jenis Kelamin

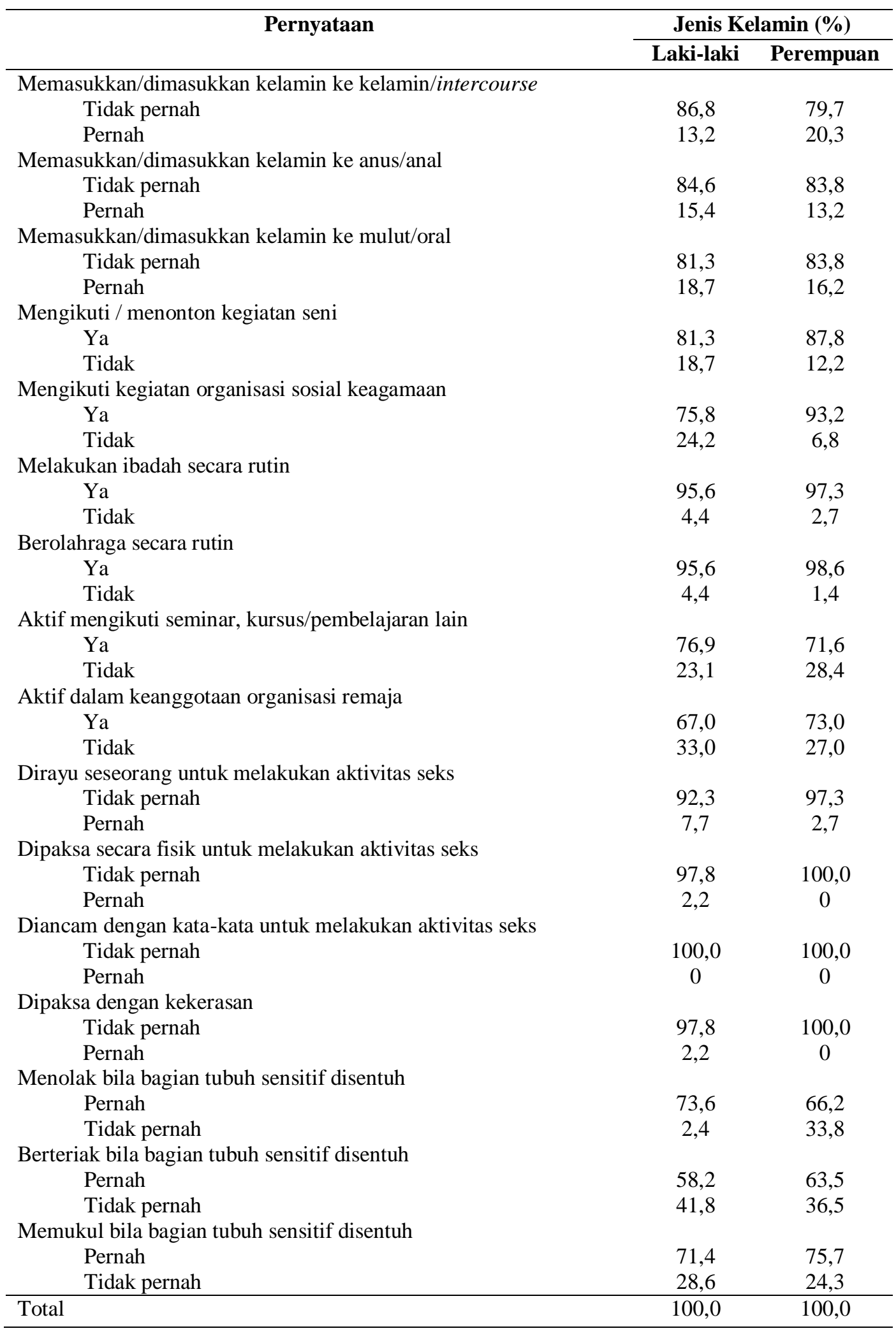

Berdasarkan tabel 4 diketahui bahwa responden laki-laki memiliki proporsi yang lebih besar untuk tidak melakukan intercourse $(57,2 \%)$ dan anal seks $(55,4 \%)$. Perempuan lebih banyak yang melakukan aktivitas menghindari hasrat seksual seperti ikut kegiatan seni, organisasi 
ibadah dan berolahraga. Semua responden perempuan tidak pernah dipaksa secara fisik, diancam dan dipaksa dengan kekerasan untuk melakukan aktivitas seksual. Responden perempuan juga lebih banyak bertindak asertif ketika bagian tubuh sensitif disentuh, seperti menolak $(66,2 \%)$, berteriak $(63,5 \%)$, dan memukul $(75,7 \%)$.

Berdasarkan tabel 5, diketahui bahwa proporsi abstinensi pada responden berjenis kelamin laki-laki lebih besar $(81,3 \%)$ daripada perempuan (78,4\%). Proporsi abstinensi tertinggi pada responden usia 12 tahun $(90,9 \%)$ sedangkan proporsi abstinensi pada usia 14 tahun menjadi yang terendah $(77,8 \%)$. Usia terendah yang pernah melakukan hubungan seksual adalah 12 tahun.

Tabel 5. Distribusi Responden berdasarkan Perilaku Abstinensi

\begin{tabular}{lcc}
\hline \multirow{2}{*}{$\begin{array}{c}\text { Karakterisitik } \\
\text { responden }\end{array}$} & \multicolumn{2}{c}{ Abstinensi (\%) } \\
\cline { 2 - 3 } & Iya & Tidak \\
\hline Jenis kelamin & & \\
Laki-laki & 81,3 & 18,7 \\
Perempuan & 78,4 & 21,6 \\
Usia (tahun) & & \\
12 & 90,9 & 9,1 \\
13 & 79,5 & 20,5 \\
14 & 77,8 & 22,2 \\
15 & 82,8 & 17,2 \\
\hline
\end{tabular}

Tabel 6. Aktivitas Menghindari Hasrat Seksual berdasarkan Perilaku Abstinensi

\begin{tabular}{lcc}
\hline \multicolumn{1}{c}{ Aktivitas menghindari hasrat seksual } & \multicolumn{2}{c}{ Abstinensi (\%) } \\
\cline { 2 - 3 } & Iya & Tidak \\
\hline Mengikuti / menonton kegiatan seni & & \\
$\quad$ Ya & 78,4 & 21,6 \\
$\quad$ Tidak & 88,5 & 11,5 \\
Mengikuti kegiatan organisasi sosial keagamaan & & \\
$\quad$ Ya & 78,3 & 21,7 \\
$\quad$ Tidak & 88,9 & 11,1 \\
Melakukan ibadah secara rutin & & \\
$\quad$ Ya & 79,9 & 20,1 \\
Tidak & 83,3 & 16,7 \\
Berolahraga secara rutin & & \\
$\quad$ Ya & 81,9 & 18,1 \\
Tidak & 20,0 & 80,0 \\
Aktif mengikuti seminar, kursus/pembelajaran lain & & \\
$\quad$ Ya & 82,1 & 17,9 \\
Tidak & 73,8 & 26,2 \\
Aktif dalam keanggotaan organisasi remaja & \multicolumn{2}{c}{} \\
$\quad$ Ya & 77,4 & 22,6 \\
Tidak & 86,0 & 14,0 \\
\hline
\end{tabular}

Berdasarkan tabel 6 diketahui bahwa responden yang berolahraga secara rutin $(81,9 \%)$ dan aktif mengikuti seminar/kursus $(82,1 \%)$ memiliki proporsi perilaku abstinensi yang lebih besar daripada yang tidak melakukan. Responden yang mengikuti/menonton kegiatan seni $(78,4 \%)$, mengikuti kegiatan organisasi sosial keagamaan $(78,3 \%)$, dan melakukan ibadah secara rutin $(79,9 \%)$, memiliki proporsi perilaku abstinensi yang lebih rendah.
Berdasarkan tabel 7 diketahui bahwa responden yang mengaku tidak mendapat inisiasi untuk melakukan aktivitas seksual, yaitu tidak pernah dirayu $(80,1 \%)$, tidak pernah dipaksa secara fisik $(80,4 \%)$, tidak pernah diancam $(80 \%)$ dan tidak pernah dipaksa dengan kekerasan $(80,4 \%)$ memiliki proporsi perilaku abstinensi yang lebih tinggi daripada yang mendapat inisiasi aktivitas seksual. Pada responden yang mengaku tidak abstinensi sebagian besar pernah mendapat inisiasi aktivitas seksual seperti dirayu dan dipaksa. 
Tabel 7. Inisiasi Aktivitas Seksual berdasarkan Perilaku Abstinensi

\begin{tabular}{lrr}
\hline \multicolumn{1}{c}{ Inisiasi aktivitas seksual } & \multicolumn{2}{c}{ Abstinensi (\%) } \\
\cline { 2 - 3 } & Iya & Tidak \\
\hline Dirayu seseorang untuk melakukan aktivitas seks & 80,1 & 19,9 \\
$\quad$ Tidak pernah & 77,8 & 22,2 \\
Pernah & & \\
Dipaksa secara fisik untuk melakukan aktivitas seks & 80,4 & 19,6 \\
$\quad$ Tidak pernah & 50,0 & 50,0 \\
Pernah & & \\
Diancam dengan kata-kata untuk melakukan aktivitas seks & 80,0 & 20,0 \\
$\quad$ Tidak pernah & 0 & 0 \\
$\quad$ Pernah & \multicolumn{2}{c}{0} \\
Dipaksa dengan kekerasan & 80,4 & 19,6 \\
$\quad$ Tidak pernah & 50,0 & 50,0 \\
Pernah & & \\
\hline
\end{tabular}

Tabel 8. Tindakan Asertif berdasarkan Perilaku Abstinensi

\begin{tabular}{lcc}
\hline \multicolumn{1}{c}{ Tindakan asertif } & \multicolumn{2}{c}{ Abstinensi (\%) } \\
\cline { 2 - 3 } & Iya & Tidak \\
\hline Menolak bila bagian tubuh sensitif disentuh & 83,6 & 16,4 \\
$\quad$ Pernah & 71,4 & 28,6 \\
$\quad$ Tidak pernah & & \\
Berteriak bila bagian tubuh sensitif disentuh & 84,0 & 16,0 \\
$\quad$ Pernah & 73,8 & 26,2 \\
$\quad$ Tidak pernah & & \\
Memukul bila bagian tubuh sensitif disentuh & 81,8 & 28,2 \\
$\quad$ Pernah & 75,0 & 25,0 \\
$\quad$ Tidak pernah & & \\
\hline
\end{tabular}

Berdasarkan tabel 8 diketahui bahwa responden yang mengaku apabila bagian tubuh sensitifnya disentuh maka pernah melakukan tindakan asertif seperti menolak $(83,6 \%)$, berteriak $(84,0 \%)$, dan memukul $(81,8 \%)$, proporsi abstinensinya lebih tinggi daripada yang tidak bertindak asertif. Pada responden yang mengaku tidak melakukan tindakan asertif seperti menolak dan berteriak, proporsi abstinensinya lebih rendah.

\section{PEMBAHASAN}

Proporsi abstinensi dalam penelitian ini sebesar 80 persen. Proporsi tersebut lebih baik dari proporsi abstinensi remaja SMP di DKI Jakarta tahun 2019, sebesar 65 persen $^{13}$. Akan tetapi tidak lebih tinggi dari hasil Survei Nasional
Berbasis Sekolah di Indonesia tahun 2015 bahwa remaja yang mengaku belum pernah melakukan hubungan seksual sebanyak 94,7 persen $^{15}$. Berbeda dengan di Amerika Serikat, Youth Risk Behavior Surveillance melaporkan terdapat 39,5 persen pelajar tingkat menengah yang sudah melakukan hubungan seksual (intercourse), artinya terdapat 61,5 persen pelajar yang abstinen ${ }^{5}$. Jika dibandingkan dengan proporsi di Amerika Serikat dan DKI Jakarta, proporsi abstinensi dalam penelitian ini jauh lebih baik. Meskipun demikian, hal ini tentu haruslah menjadi perhatian bagi seluruh pihak, sebab abstinensi seks yang rendah serta berkelanjutan dapat berdampak pada moral remaja ${ }^{4}$.

Dari segi usia, proporsi abstinensi tertinggi pada kelompok usia terendah, yaitu 12 tahun. Hal ini sejalan dengan hasil systematic review 
artikel di Asia, Afrika, Australia, Eropa dan Amerika Utara, dengan proporsi abstinensi terbesar pada remaja awal usia 10-14 tahun ${ }^{11}$. Akan tetapi, pada usia tersebut (12 tahun) juga menjadi usia termuda untuk melakukan hubungan seksual. Sedikit berbeda dengan hasil Survei Nasional Berbasis Sekolah di Indonesia tahun 2015 bahwa sejumlah pelajar di Indonesia pernah melakukan hubungan intim seperti suami-istri pertama kali pada usia 11 tahun dan lebih muda $(0,78 \%)^{15}$. Penelitian lain bahkan menemukan pengakuan responden yang melakukan aktivitas seksual pertama kali pada usia 6 tahun $^{13}$. Usia 12 tahun sebagaimana diketahui merupakan usia pelajar kelas 1 SMP. Usia tersebut masuk ke dalam kelompok remaja awal. Pada usia tersebut, remaja memasuki masa pubertas yang secara fitrah muncul ketertarikan kepada lawan jenis, namun remaja seharusnya masih abstinensi seks. Remaja juga masih mengalami pertumbuhan dan perkembangan fisik, psikis dan kognitif. Hubungan seksual pranikah dapat membawa dampak negatif seperti kehamilan yang tidak diinginkan yang berakibat pada aborsi, penularan IMS dan HIV-AIDS, trauma kejiwaan, serta kemungkinan tidak melanjutkan pendidikan. Oleh sebab itu, lingkungan sekitar sangat perlu memberikan pengertian dan bimbingan agar remaja dapat tumbuh dan berkembang menjadi generasi yang sehat ${ }^{3}$.

Berdasarkan jenis kelamin, remaja laki-laki lebih banyak melaporkan abstinensi $(81,3 \%)$ daripada perempuan. Berbeda dengan penelitian sebelumnya dimana remaja laki-laki lebih banyak melaporkan sudah melakukan hubungan seksual. Dalam Survei Nasional Berbasis Sekolah di Indonesia tahun 2015, proporsi laki-laki yang melaporkan sudah berhubungan seksual lebih banyak dari perempuan $(6,91 \%)^{15}$. Hasil penelitian ini justru sejalan dengan dengan hasil penelitian di Accra, Ghana, bahwa abstinensi pada laki-laki lebih tinggi. Di Ghana, sebagian besar Afrika, remaja perempuan biasanya ditekan untuk berhubungan seksual dengan laki-laki dewasa dengan alasan keuangan dan dukungan sosial, bahkan norma budaya secara halus mendorong hubungan seksual semacam itu. Hal ini terutama terjadi di daerah dengan akses terbatas ke sumber daya dasar seperti lingkungan miskin $^{12}$. Akan tetapi, dalam penelitian ini tingginya abstinensi pada remaja laki-laki tidak dikarenakan oleh faktor ekonomi dan budaya, melainkan bisa dikarenakan responden malu dan tidak terbuka saat menjawab kuesioner.

Dalam mempertahankan abstinensi, remaja menghindari hasrat seksual dengan melakukan kegiatan positif. Perempuan lebih banyak yang melakukan kegiatan positif tersebut. Proporsi abstinensi lebih tinggi pada mereka yang rutin berolahraga $(81,9 \%)$ serta mengikuti seminar/kursus $\quad(82,1 \%)$. Kegiatan-kegiatan positif tersebut dapat dilakukan di waktu luang setelah waktu belajar di sekolah. Penelitian pada siswa SMP memperoleh hasil bahwa waktu luang diisi dengan kegiatan positif seperti mengikuti kegiatan sosial dan berolahraga ${ }^{18}$. Dengan mengikuti kegiatan positif dalam mengisi waktu luangnya, siswa menjadi lebih aktif, kreatif, percaya diri, memberi kesempatan bersosialisasi dan berdampak pada pembentukan karakter yang baik. Untuk itu, remaja dianjurkan untuk aktif dalam kegiatan ekstrakulikuler and organisasi di sekolah serta berolahraga yang biasanya dilaksanakan setelah waktu belajar di sekolah usai. Salah satunya bisa melalui Pusat Informasi dan Konseling Remaja (PIKR) di lingkungan sekolah ataupun masyarakat ${ }^{19}$. Melalui PIKR remaja bisa memperoleh informasi seputar kesehatan reproduksi, triad KRR (seksualitas, HIV dan AIDS serta napza), keterampilan hidup (life skills), untuk merencanakan hidup yang berkualitas di masa yang akan datang ${ }^{20}$.

Selanjutnya, responden yang aktif mengikuti kegiatan seni, berorganisasi sosial keagamaan serta rutin beribadah memiliki proporsi abstinensi lebih rendah. Rutin beribadah dan hadir dalam kegiatan keagamaan menunjukkan religiusitas $^{21}$. Hal ini tidak sejalan dengan penelitian di Nigeria yang memperoleh hasil bahwa religiusitas menjadi faktor protektif dari perilaku seksual. Remaja dengan tingkat religiusitas yang tinggi berpeluang 2 kali lebih besar untuk berperilaku abstinensi ${ }^{9}$. Agama menanamkan nilai-nilai positif yang berhubungan dengan pembentukan kepribadian anak agar anak memiliki pondasi yang kuat dan tidak mudah goyah dengan keadaan serta bertanggung jawab ${ }^{22}$. Agama merupakan landasan dalam edukasi terkait pubertas ${ }^{23}$, termasuk reproduksi, dan seksualitas. Akan tetapi dalam penelitian ini, aktif dalam organisasi sosial dan keagaamaan dan rutin beribadah nampaknya tidak menunjukkan keterkaitan dengan perilaku abstinensi, sebab 
proporsi abstinensi pada responden yang tidak mengikuti organisasi sosial keagamaan dan rutin beribadah lebih kecil. Hal ini dapat dikarenakan pertanyaan yang terlalu sederhana untuk menilai religiusitas seseorang yang hanya ditanyakan dalam hal beribadah rutin saja. Responden dapat mengisi tidak rutin apabila pernah satu atau dua kali melewatkan ibadah harian seperti sholat lima waktu dalam Islam. Oleh sebab itu sebaiknya dalam menilai religiusitas perlu menggali juga aspek pengetahuan keagamaan dan ibadah wajib lainnya.

Inisiasi aktivitas seksual dilihat dari upaya adanya rayuan, paksaan dan ancaman. Hampir semua responden yang abstinensi dalam penelitian ini mengaku tidak pernah dirayu, dipaksa secara fisik dan dipaksa dengan kekerasan, bahkan semua responden tidak pernah diancam untuk melakukan aktivitas seksual. Seluruh responden perempuan melaporkan tidak pernah dipaksa secara fisik, diancam dan dipaksa dengan kekerasan. Hasil penelitian ini berada pada kisaran yang sama dengan hasil Survei Nasional Berbasis Sekolah di Indonesia tahun 2015 yaitu 95,7 persen responden tidak pernah dipaksa melakukan hubungan seksual dengan proporsi 94,8 persen laki-laki dan perempuan 96,5 persen ${ }^{15}$. Proporsi tersebut lebih baik daripada remaja di DKI Jakarta, yaitu terdapat 25,5 persen dirayu dan 3,6 persen diancam untuk melakukan aktivitas seksual, yang artinya ada lebih banyak responden yang pernah dirayu dan diancam untuk melakukan aktivitas seksual ${ }^{13}$. Akan tetapi, perlu juga diperhatikan, seperti hasil penelitian pada beberapa remaja di Surabaya, beberapa informan laki-laki merasa hampir tidak ada kesulitan untuk mengajak pasangannya melakukan hubungan seksual. Aktivitas seksual seringkali terjadi begitu saja, sehingga tidak ada upaya untuk penolakan pada aktivitas tersebut ${ }^{24}$. Dengan demikian, tanpa adanya inisiasi melakukan aktivitas seksual (dirayu, dipaksa, diancam) pun remaja dapat melakukan aktivitas seksual terutama dilakukan dengan pasangan atau pacar. Status berpacaran dapat meningkatkan risiko melakukan perilaku pacaran berisiko. Setelah berstatus pacaran, kemudian dapat berlanjut pada tahap berikutnya seperti berciuman bibir (kissing), cium leher (necking), saling menempelkan alat kelamin (petting), dan memasukkan kelamin ke kelamin (intercourse) $^{25}$. Dalam SDKI 2017, dilaporkan
30 persen remaja wanita dan 50 persen pria melakukan ciuman bibir, serta 5 persen wanita dan 21 persen pria pernah meraba/diraba tubuhnya ${ }^{2}$. Peran orang tua sangatlah penting untuk menjaga lingkungan pergaulan anaknya serta melakukan pengawasan agar terhindar dari perilaku seksual.

Apabila terdapat ajakan, rayuan, paksaan dan ancaman untuk melakukan aktivitas seksual, remaja harusnya melakukan tindakan asertif yang ditunjukkan dengan upaya menolak, berteriak, memukul, dan menghindar. Sebagian besar responden penelitian ini mengaku pernah bertindak asertif apabila baigan tubuh sensitifnya disentuh. Responden yang pernah menolak, berteriak dan memukul memiliki proporsi perilaku abstinensi lebih tinggi daripada yang tidak pernah bertindak asertif. Tindakan asertif tersebut berada dalam kisaran yang sama dengan sebuah penelitian pada remaja perempuan di Bandung bahwa 80 persen remaja memiliki tindakan asertif yang tinggi. Tindakan asertif atau ketegasan terhadap seksual yaitu bertindak tegas dan mengambil keputusan seksual mereka dengan menghormati hak-hak orang lain, dan mengekspresikan diri mereka dengan jujur dengan cara yang benar tanpa perasaan cemas yang mengganggu. ${ }^{(26)}$ Jika remaja mampu mempertimbangkan risiko perilaku seksual maka remaja akan mampu mengelola dorongan seksualnya secara baik dan dapat disalurkan secara sehat serta bertanggung jawab $^{27}$.

Dalam penelitian ini proporsi tindakan asertif yang tinggi seolah menampakkan situasi remaja yang negatif karena sebagian besar pernah melakukan upaya asertif ketika mengalami adanya sentuhan di bagian tubuh sensitifnya yang dinilai sebagai upaya awal aktivitas seksual. Hal ini mungkin saja terjadi mengingat perilaku berpacaran remaja masa kini yang berisiko. Berdasarkan hasil analisis diketahui bahwa responden yang tidak abstinensi sebagian besar tidak melakukan tindakan asertif, artinya mereka permisif dengan upaya inisiasi aktivitas seksual. Tindakan asertif memerlukan dorongan yang sangat kuat untuk menghindari terjadinya aktivitas seksual. Salah satu yang dapat menguatkan adalah keimanan atau religiusitas yang kuat. Untuk itu penanaman ilmu agama di dalam keluarga sejak dini sangatlah penting ${ }^{22}$. Hal ini diperlukan 
dalam rangka mencapai visi Generasi Emas Indonesia $2045^{28}$.

\section{KESIMPULAN}

Perilaku abstinensi remaja usia SMP di Kota Tangerang Selatan masih cukup tinggi (80\%), meskipun pada usia yang sangat muda (12 tahun) ada yang sudah melakukan hubungan seksual. Sebagian besar remaja melakukan kegiatan positif untuk menghindari hasrat seksual dengan berolahraga rutin dan mengikuti kursus. Inisiasi aktivitas seksual seperti rayuan dan paksaan sebagian besar tidak dirasakan oleh responden yang abstinensi. Tindakan asertif apabila bagian tubuh sensitifnya disentuh menunjukkan proporsi yang cukup tinggi pada responden yang abstinensi, namun pada yang tidak abstinensi tidak menunjukkan tindakan asertif sehingga aktivitas seksual dapat dilakukan begitu saja tanpa ada inisiasi ataupun upaya penolakan.

\section{SARAN}

Health education on menstrual problems targeting schoolgirls and their mothers, and routine screening for menstrual problems by healthcare providers, can help prevent school absenteeism. As mothers were the main source of information and knowledge among schoolgirls in this study, health professionals should involve mothers in general discussions about menstrual problems and how to deal with them.

\section{UCAPAN TERIMA KASIH}

Terima kasih kepada Fakultas Kesehatan Masyarakat Universitas Muhammadiyah Jakarta serta seluruh mahasiswa FKM UMJ Angkatan 2018.

\section{DAFTAR PUSTAKA}

1. Badan Pusat Statistik (BPS). Profil Penduduk Indonesia Hasil Supas 2015 [Internet]. 2015. 273 p. Available from: https://www.bps.go.id
2. BKKBN, BPS, Kemenkes, USAID. Survei Demografi Dan Kesehatan: Kesehatan Reproduksi Remaja 2017 [Internet]. 2018. Available from: http://www.dhsprogram.com.

3. Kumalasari; I, Andhyantoro I. Kesehatan Reproduksi Remaja. Jakarta: Salemba Medika; 2012. 19-20 p.

4. Widyastuti DA. Profil Dan Pentingnya Sexual Abstinence Pada Remaja Untuk Membentuk Generasi Yang Bermoral. In: The 5th Urecol Proceeding. Yogyakarta: Universitas Ahmad Dahlan; 2017. p. 8329.

5. CDC. Sexually Transmittied Diseases Treatment Guidelines. Vol. 64, Morbidity and Mortality Weekly Report. 2015.

6. Mokwena K, Morabe M. Sexual abstinence: What is the understanding and views of secondary school learners in a semi-rural area of North West Province, South Africa? Sahara-J J Soc Asp HIV/AIDS $\backslash$ [Internet]. 2016;13(1):81-7. Available from: https://doi.org/10.1080/17290376.2016.11 95281

7. Santelli JS, Kantor LM, Grilo SA, Speizer IS, Lindberg LD, Heitel J, et al. Abstinence-Only-Until-Marriage: An Updated Review of U.S. Policies and Programs and Their Impact. J Adolesc Heal [Internet]. 2017;61(3):273-80. Available from: http://dx.doi.org/10.1016/j.jadohealth.201 7.05 .031

8. Zeiler A. Abstinence Education. Linacre Q [Internet]. 2014;81(4):372-7. Available from: https://journals.sagepub.com/doi/abs/10.1 179/0024363914Z.00000000088

9. Somefun OD. Religiosity and Sexual Abstinence among Nigerian Youths: Does Parent Religion Matter? BMC Public Health [Internet]. 2019;19(1):1-11. Available from: https://pubmed.ncbi.nlm.nih.gov/3099989 $0 /$

10. Laura Kann et al. Youth Risk Behavior Surveillance. Morb Mortal Wkly Rep [Internet]. 2018;67(8). Available from: https://www.cdc.gov/mmwr/volumes/67/s 
s/ss6708a1.htm

11. Irfan M, Hazlina N, Hussain N, Med MO, Noor NM. Sexual Abstinence and Associated Factors Among Young and Middle-Aged Men : A Systematic Review Characteristics of Included Studies. J Sex Med [Internet]. 2020;17(3):412-30. Available from: https://doi.org/10.1016/j.jsxm.2019.12.00 3

12. Alhassan N, Dodoo FNA. Predictors of Primary and Secondary Sexual Abstinence among Never-Married Youth in Urban Poor Accra, Ghana. Reprod Health [Internet]. 2020;17(1):1-13. Available from: https://reproductive-healthjournal.biomedcentral.com/articles/10.118 6/s12978-020-0885-4

13. Nurfadhilah, Ariasih AR. Abstinensi dan Pendidikan Seks Remaja: Survei Cepat di Jakarta dan Sekitarnya. Pendidik Lingkung dan Pembang Berkelanjutan [Internet]. 2019;XX(Maret 2019):17-28. Available from:

http://journal.unj.ac.id/unj/index.php/plpb /article/view/9988

14. Saputri YI, Hidayani H. Faktor - Faktor yang Berhubungan dengan Perilaku Seks Pra Nikah Remaja. J Ilmu Kesehat Masy [Internet]. 2017;5(4):52-62. Available from:

http://journals.stikim.ac.id/index.php/jikm /article/view/314

15. Puslitbang Upaya Kesehatan Masyarakat. Perilaku Berisiko Kesehatan pada Pelajar SMP dan SMA di Indonesia. Hasil Survey Nasional Berbasis Sekolah di Indonesia [Internet]. Badan Litbangkes Kementrian Kesehatan RI. Jakarta; 2015. Available from:

http://www.who.int/ncds/surveillance/gsh s/GSHS_2015_Indonesia_Report_Bahasa. pdf?ua=1

16. Parihat RD. Perilaku Berisiko dan Faktor Risiko Kejadian Seks Pranikah pada Siswa/Siswi SMA Sederajat di Kota Tangerang Selatan Tahun 2015. UIN Syarif Hidayatullah Jakarta; 2015.

17. Kania L, Okta T. Faktor-Faktor Yang Berhubungan Dengan Perilaku Seks Bebas Pada Mahasiswa Di Tangerang Selatan. Edu Masda J [Internet]. 2018;2(1):13-4.
Available

from: http://openjournal.masda.ac.id/index.php/ edumasda/index

18. Yusnita;, Arlizon R, Umari T. Analisis Penggunaan Waktu Luang Siswa SMP Negeri 3 Pujud di luar Jan Sekolah Tahun Pelajaran 2013 / 2014. J Online Mhs Bid Kegur dan Ilmu Pendidik [Internet]. 2015;2(1). Available from: https://jom.unri.ac.id/index.php/JOMFKI P/article/view/5686/5562

19. Sabilla M, Febrianti T, Efendi R. Analisis Perilaku Dan Kebutuhan Informasi Kesehatan Reproduksi Melalui Pusat Informasi Konseling Remaja. J Kesehat Indra Husada [Internet]. 2019;7(1):1. Available from: https://doi.org/10.36973/jkih.v7i1.153

20. BKKBN. Pedoman Pengelolaan Pusat Informasi dan Konseling Remaja dan Mahasiswa (PIK Remaja/Mahasiswa). Jakarta: BKKBN; 2015.

21. Cerqueira-Santos E, Koller S. Sexual risktaking behavior: The role of religiosity among poor Brazilian youth. Univ Psychol [Internet]. 2016;15(4):1-9. Available from:

http://www.scielo.org.co/scielo.php?script $=$ sci_arttext $\&$ pid $=$ S 1657 -

92672016000400014

22. Maulidiyah EC. Penanaman Nilai-Nilai Agama Dalam Pendidikan Anak Di Era Digital. Martabat J Peremp dan Anak [Internet]. 2018;2(1):72-90. Available from:

https://media.neliti.com/media/publication s/276725-penanaman-nilai-nilai-agamadalam-pendid-734379ad.pdf

23. Utomo E, Nurfadhilah, Purwanto A, Wicaksono JW, Arif A. Landasan Agama dalam Pendidikan Pubertas di Sekolah Dasar. J Harkat Media Komun Gend [Internet]. 2019;4(Dec 2019):55-60. Available from: http://journal.uinjkt.ac.id/index.php/psga/ article/view/13440

24. Indah D, Prabandari YS, Wahyuni B. Asertivitas Remaja Terhadap Perilaku Seksual Pranikah ( Studi Kualitatif pada Remaja di Surabaya ). Jukmas J Untuk Masy Sehat [Internet]. 2018;2(2):229-40. Available

from: 
http://ejournal.urindo.ac.id/index.php/juk mas/article/view/589

25. Ohee C, Puromo W. Pengaruh Status Hubungan Berpacaran Terhadap Perilaku Pacaran Berisiko Pada Mahasiswa Perantau Asal Papua Di Kota Surabaya. Indones $\mathbf{J}$ Public Heal [Internet]. 2019;13(2):269. Available from: https://ejournal.unair.ac.id/IJPH/article/view/8237

26. Fathimiyah I, Amartha VA, Rahayuwati L, Rafiyah I. Self Esteem, Assertiveness, and Sexual Behaviour in Adolescent Girls. In: Conference Book International Conference on Health Care and Management [Internet]. 1st ed. Bandung; 2018. Available from: http://ichm2018.stikepppnijabar.ac.id/index.php/ichm2018/articl e/view/14

27. Ayu IP, Marwiyah N. Pengaruh Sikap Asertif dan Konsep Diri Terhadap Perilaku Seksual Pranikah Siswa SMP Negeri di Kota Serang. Falatehan Heal J [Internet]. 2019;6(2):56-63. Available from: www. journal.lppmstikesfa.ac.id/ojs/index.php/FHJ

28. Nurfadhilah. Analisis Pendidikan Karakter Dalam Mempersiapkan Pubertas Menuju Generasi Emas Indonesia 2045. J Pendidik Dasar [Internet]. 2019;10(1):85-100. Available from: http://journal.unj.ac.id/unj/index.php/jpd/a rticle/view/11124 